\title{
Empirical Determinants of Saving in the Islamic Banks: Evidence from Indonesia
}

\author{
Rahmatina A. Kasri and Salina Hj. Kassim \\ Researcher, Islamic Economics and Business Center (PEBS) Lecturer, \\ Department of Economics, \\ Faculty of Economics and Business, University of Indonesia \\ rahmatina@ui.edu and unirahma@yahoo.com \\ and Assistant Professor, Depart. of Economics, \\ Kuliyyah of Economics and Management Sciences, \\ International Islamic University of Malaysia. \\ ksalina@iiu.edu.my
}

\begin{abstract}
This study attempts to determine the factors affecting saving in the Islamic banks in Indonesia. By employing the Vector Autoregressive and its associated Impulse Response Function analysis for all Islamic banks in Indonesia from March 2000 to August 2007, the study analyzes the importance of real rate of return on Islamic deposit, interest rate on conventional deposit, real income and number of Islamic bank branches in determining the level of savings in the Islamic banks. The results highlight the influential role of conventional interest rate in determining the level of saving in the Islamic banks. In particular, higher Islamic deposit is significantly correlated with higher rate of return and lower interest rate. Furthermore, the study finds the existence of displaced commercial risk between the Islamic and conventional banks, such that the Islamic banks' depositors transfer their funds to the conventional banks when the rate of return provided by the Islamic banks is significantly lower than the interest rate of its counterpart. The findings of this study have important implications on the risk management practices in the Islamic banks in Indonesia.
\end{abstract}

\section{Introduction}

According to conventional economics, saving is the excess of income over consumption expenditure (Keynes, 1936). Saving is intended to meet future consumption as well as to provide means for investment. As people save and forgo their current consumption, the 'sacrifice' must be rewarded by positive- 
additional amount to their saving. The positive time value of money implies that the desire to get the additional amount, or simply profit seeking motive, is recognized as the main reason for saving in the conventional banking institutions. Consequently, saving is primarily determined by the rate of return on the saving. These institutions are preserved by the practice of rewarding interest on deposits.

Islam is, however, against any practices that provide excess in return of which no reward or equivalent counter-value is paid, better known as riba. In the banking context, since the 1960s the prohibition of interest (usury) has been one of the most discussed issues amongst Muslims. This is a consequence of both the perception that bank interest is riba and the prevailing nature of interest of the present world of banking system. Initially, contemporary Muslim scholars are different as to whether the prohibition of riba applies to modern bank's interest. Nonetheless, today there is a general consensus that interest on bank loans is considered as riba and therefore strictly prohibited in Islam. The strict prohibition of interest in Islam is a result of its deep concern for the moral, social, and economic welfare of mankind. The prohibition of interest is followed by the encouragement of various trading and equity-based investment activities. (Usmani, 2005).

Based on this background, this study attempts to investigate the determinants of saving in the Islamic banks in Indonesia. It is indeed very important to understand the determining factor in influencing saving among the customers so as to appreciate the reasons or motivations of the customers patronizing the Islamic banks. In this regard, several studies have been conducted based on the Malaysian context, Haron and Shanmugam, 1995; Haron and Ahmad, 2000; Sukmana and Yusof, 2005). However, studies on Indonesia - a country which has the largest Muslim population in the world have been quite lacking. Interestingly, current studies based on the Indonesian experience have been inconclusive and contradictory. Surveys conducted by Indonesian Central Bank on the public preference towards Islamic banks reveal that religiosity was among the major reasons in selecting Islamic banking products (Bank Indonesia, 2005). In contrast, Mangkuto (2004) observes the existence of profit motive among the Islamic bank's customers. The existence of profit motive has many implications, one of which is the tendency of depositors to withdraw their fund and remove it to conventional bank if the latter offers higher return (interest rates). This situation, if not managed properly, has a potential to lower growth of the Islamic banks. Therefore, this study attempts to fill in the gap and empirically evaluate whether the depositors are influenced by return on the deposits or other exogenous variables religious or profit motive by investigating the relationship between Islamic banks' deposits and its determinants such as rate of return, interest rate of conventional 
bank, national income, and network of the Islamic banks. Further, results of this study are expected to contribute toward better risk management practices of the Islamic banks in Indonesia.

The remainder of this paper is organized as follows. Section 2 provides a brief overview of the history and development of the Islamic banking industry in Indonesia. Section 3 reviews the relevant literature, while Section 4 discusses the data and methodology. Section 5 presents the empirical results and discusses the findings and, finally, Section 6 concludes.

\section{History and Development of Islamic Banks in Indonesia}

The history of Islamic banks in Indonesia can be traced back to 1990, when the conference of Majelis Ulama Indonesia (Indonesian Jurist Council) was held in Cisarua, West Java, Indonesia. The conference was motivated by the fact that many of Indonesian Muslims started to demand interest-free banking products and services in line with the requirements of the shari'ah. It was during this conference that a proposition to establish an Islamic bank was made. Thus, it can be seen as an important milestone in Islamic resurgence in the area of economics, banking and finance in Indonesia.

Following the conference, continuous efforts have been made to put the idea into practice. It is important to note that, at the early stages, the ulama (Islamic scholars) and academicians were the initiators of the Islamic bank idea. However, the concept of the Islamic bank was still unfamiliar to bankers and regulators. Moreover, the existing banking regulation at that time, namely the Banking Act No. 14/1968, was unable to accommodate ${ }^{(1)}$ the so-called Islamic bank to operate in the country. However, from a regulatory point of view, it was the issuance of the new banking act, Banking Act No. 7/1992 that gave an opportunity to establish the Islamic banks. Having struggled on a long journey, on November 1992 the first Indonesian Islamic bank, Bank Muamalat Indonesia (BMI), was inaugurated. Yet, it is important to note that even under the new Banking Act No. 7/1992, BMI was actually recognized as a "profit-sharing bank" rather than as an "Islamic bank ${ }^{(2) \text { ". }}$

A clearer regulatory acknowledgment of the existence of the Islamic banks in the Indonesian banking system was first mentioned in the Banking Act No. 10/1998 as an amendment to the Banking Act No. 7/1992. In the new Banking Act, it is stated that commercial banks in Indonesia can operate in the conventional way (based on the interest rate system) or based on the shari'ah

(1) Notice that the Banking Act No. 14/1968 recognizes interest as the only basis for banking operations.

(2) The terms such as "Islamic Bank", "Shari'a Bank", "Islamic Principle" or "Shari'a Principle" were never mentioned in the Banking Act No.7/1992. Fortunately, all of those terms are readily found in the Banking Act No. 10/1998 which amended the previous one. 
principles. It is also important to note that the new regulation allows a conventional bank to open a shari'ah branch office with the aim of boosting the development of the industry. Furthermore, after the establishment of the new Central Bank Act No. 23/1999, the importance of the Islamic banking industry was strengthened. Under this regulation, Bank Indonesia as the central bank is mandated to regulate, supervise and develop the Islamic banks.

Another important milestone in the development of the Islamic banking industry in Indonesia took place in 2002 when Bank Indonesia launched the "Blueprint of Islamic Banking Development in Indonesia". The blueprint contains the vision, mission, and strategic objectives to be achieved by Islamic banks in the country. Among others, the Islamic banking industry in Indonesia is targeted to capture 5 percent of the total market share of the banking industry by year $2009^{(3)}$. Further, just recently, the government issued the Islamic Banking Act No.21/2008 that provides a legal basis for further development of the industry in Indonesia.

Despite its relatively new existence in the Indonesian financial system, the Islamic banking and finance industry is a fast growing industry and continues to stage impressive performance. Started off as a single bank during the 1992-1998 period, as of July 2008 there are three full-fledged Islamic banks, 28 Shari'ah Banking Unit (UUS), 128 BPRS, and 1394 Islamic bank offices in the conventional banks' branches (as part of the office channeling policy). In terms of financial indicators, as a result of the aggressive efforts to support growth of the industry, the Islamic banking industry in Indonesia grew rapidly at around 64 percent annually (2003-2007), surpasses that of the global Islamic banking industry (15-20 percent annual growth) during the corresponding period (Bank Indonesia, 2007).

Savings in the Islamic banks in Indonesia are mobilized through three types of accounts, namely Wadi ah current account, mudharaba savings account, and mudharaba investment account. Wadi ah current account, or trust account, is a current account based on Islamic principle of wadi ah (trust) ${ }^{(4)}$. Mudarabah accounts, in contrast, are account based on mudarabah (profit-loss-sharing) contract. Under mudarabah principle, depositors (sahib al-mal) deposit their fund to bank (as mudarib or fund manager), which later invest the funds into shari'a compliance business activities or projects and share the profit/loss with the depositors. The difference is that, under the mudarabah savings account, the

(3) This target had been expedited to 2008 in view of the encouraging performance of the Islamic banking industry. The target, however, was not achieved by end-2008.

(4) Under this mechanism, the deposits are held as amanah or in trust and utilized by the bank at its own risk. The depositor does not share in the risk or return in any form. Any profit or loss resulting from the investment of these funds accrues entirely to the bank. Another feature of such deposits is the absence of any condition with regard to deposits and withdrawals. 
depositor can withdraw their funds at any time. Meanwhile, under the mudarabah investment account, they can only withdraw the funds at the maturity $(1,3,6 \text { or } 12 \text { months })^{(5)}$. Put it in the conventional bank's perspective, mudarabah savings account is similar to savings account while mudharaba investment account is similar to time deposit, yet both are based on the Islamic principle of mudharaba. As portrayed in Fig. 1, most of the funds are mobilized through mudarabah investment account (close to 60 per cent), somewhat indicating that most of the depositors have profit motive in using the Islamic banks' services. In the near future, as more domestic and foreign Islamic banks are expected to operate in Indonesia, the industry is expected to sustain rapid growth in line with the strong growth of the Islamic banking and finance industry globally.

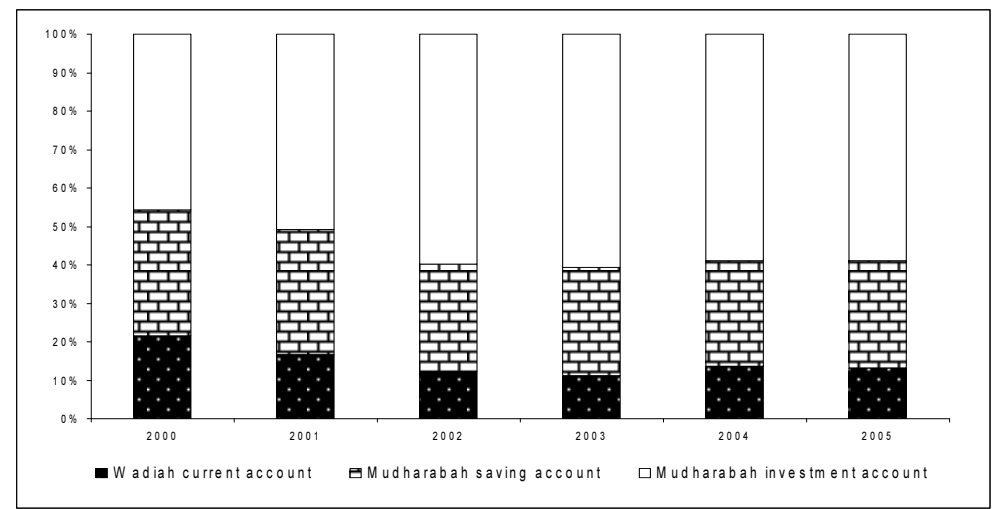

Source: Data from Bank Indonesia, 2005.

Fig. 1. Composition of Islamic Bank's Funds.

\section{Literature Review}

Keynes (1936) defined saving as the excess of income over consumption expenditure, or simply, saving is a function of income. This is known as the Absolute Income Hypothesis. Extending the Keynesian perspective, Modigliani and Brumberg (1954) proposed the life-cycle model which emphasizes that the main motive of saving is the accumulation for retirement ${ }^{(6)}$. The model is built

(5) Bank Indonesia (2008), Kodifikasi Produk Perbankan Syariah [Codification of Islamic Banking Product in Indonesia], pp: A-1.

(6) Modigliani and Brumberg (1954) also distinguished four main motives for savings, namely to increase the estate of one's heirs (altruistic behavior), to adjust income to irregular consumption, to meet possible emergencies (i.e., the precautionary motives) and to accumulate assets/equity in order to reduce uncertainty about present and future income (pp: 391-393). However, given the objective to maximize an agent's lifetime utility, the life-cycle model emphasizes the role of accumulation (of assets) for retirement. They argued that "any one asset in the individual's 'portfolio' may, and usually will, satisfy more than one motive simultaneously" (p.393) and therefore focused on the latest motive in their model. 
around the consumption/saving behavior of an economic agent who is assumed to maximize the present value of lifetime utility, subject to a budget constraint. The model predicts that consumption in a particular period depends on expectations about lifetime income. As income tends to fluctuate systematically over the course of a person's life, saving behavior is also significantly determined by one's stage in the life-cycle. Hence, individuals smooth consumption over their lifetimes such that they become net savers during their working years and dis-savers during retirement.

Earlier work by Jalaluddin (1992) argues that, in contrast to the Keynes' absolute income hypothesis, saving is not merely a 'residual' concept, in the sense that what is left over from consumption is treated as saving where no ethical values and social responsibilities are attached. A Muslim saves to perform his duties to himself, family, society, and Almighty Allah, which definitely require economic backing. Thus, there is a social welfare dimension to the savings behavior of a Muslim. In fact, as savings are invested, economically rewarding opportunities will increase which is expected to increase the welfare of Muslim ummah.

Furthermore, he argued that the life-cycle hypothesis proposed by Modigliani and Brumberg (1954) can work in the framework of Muslim's saving behavior. The four motives of saving proposed in the life-cycle model ${ }^{(7)}$ are consistent with Islamic norm behaviors. These motives are evident not only contemporarily, but also during the prophet's (pbuh) time. A Qur'anic verse, for example, states that a Muslim should "...not spend everything so that you became blameworthy and destitute" (al-Qur'an 17:29), hence emphasizes the importance of savings. Many hadiths also suggest the similar motives. For instance, a hadith from al-Bukhari mentions that " Narrated by Umar: the holy prophet (pbuh) used to sell the dates of the gardens of Bani Nadir and store for his family so much as would cover their needs for a whole year". (al-Asqalany, 2003). The hadith clearly shows that saving is particularly important to meet the emergency and future needs, not only for an individual but also for his/her family.

The normative aspects are later developed into empirical models. Several empirical studies have attempted to see the customers' selection determinants

(7) Modigliani and Brumberg (1954) also distinguished four main motives for savings, namely to increase the estate of one's heirs (altruistic behavior), to adjust income to irregular consumption, to meet possible emergencies (i.e., the precautionary motives) and to accumulate assets/equity in order to reduce uncertainty about present and future income (pp: 391-393). However, given the objective to maximize an agent's lifetime utility, the life-cycle model emphasizes the role of accumulation (of assets) for retirement. They argued that "any one asset in the individual's 'portfolio' may, and usually will, satisfy more than one motive simultaneously" (p.393) and therefore focused on the latest motive in their model. 
for using the services of Islamic bank. These studies mainly focus on the relationship between Islamic banks deposit, rate of return of Islamic banks and interest rate of conventional banks. For example, Haron and Shanmugam (1995) examine the relationship between rate of return offered by Bank Islam Malaysia Berhad and the level of deposit in the bank over the period 1983-1993. The result shows an inverse relationship between the variables, implying that Islamic bank customers did not consider returns from the deposit as an incentive to maintain funds with the banks. More recent study by Haron and Ahmad (2000) further provide support to the conclusion that Islamic bank customers are guided more by the profit motive. By expanding the previous study to include all funds deposited in the Islamic banks in Malaysia, the result of the study indicates that the rates of profit have a strong positive relationship with Islamic banks' deposits, while the interest rates have a strong negative relationship with it. The result of this study is confirmed by Sukmana and Yusof (2005) who performed the same study for all Islamic banks in Malaysia from January 1994 to October 2004.

In the case of Indonesia, Mangkuto (2004) applied a similar study for the case of Bank Muamalat Indonesia. The study examines the effect of mudarabah deposit yield in the bank and interest rate in the conventional bank on the level of the Islamic deposit. Positive correlation between the level of the deposit and its yield is found during January 2000 - July 2004 period, indicating that higher return leads to higher level of the deposit. In contrast, the conventional interest rate is negatively correlated with the deposit yield, implying the importance of conventional interest rate in influencing the decision to save in the Islamic banks. This implies the existence of profit motive among the Islamic bank's depositors. The scope of the study is later widened by Rohmah (2006) to cover all Islamic banks in Indonesia from March 2000 to February 2006. Using Autoregressive Distributive Lag (ARDL) model, it is shown that the mudarabah investment deposit in the Islamic banks are cointegrated with return of the Islamic deposit, interest rate of the conventional banks' deposit, number of Islamic banks' branches, and national income in the long-run.

In addition to these empirical studies, several studies have been conducted to investigate the factors that determine the behavior of Islamic banks' depositors by using qualitative methods and surveys. In contrary to the general findings of the empirical studies, most of the studies found that profit motive did not appear to be a major driver of the behavior of Islamic banking customer. Instead, religion is suggested as the main reason for choosing Islamic bank, together with Islamic banks specific factor such as cost and benefit of products/services offered (products prices and rate of return of the investment), service quality (fast/efficient service and friendliness of the bank's staff), size and reputation of the bank, convenience (location and ample parking space) and 
friends/families influences (see, among others, Haron et al., 1994; Metawa and Almossawi, 1998; Almossawi, 2001; Naser et al., 1999; Bank Indonesia, 20002005). A recent study by Dusuki and Abdullah (2007) adds that corporate social responsibility activities are seen as important determinants in dealing with Islamic banks in Malaysia.

In Indonesia, studies on potency, preference, and people's behavior toward Islamic bank have also been done by the central bank in year 2000 to 2005 . The study is performed with collaboration with several universities to cover at least 11 provinces in Indonesia ${ }^{(8)}$. The studies reveal that although religiosity is perceived as one of the main reasons in dealing with Islamic banks in Indonesia, the perception on interest rate is ambiguous. While most of the respondents agreed that interest rate is prohibited in Islam, they are not strongly against the interest rate application in the banking system (Bank Indonesia, 2005).

\section{Data and Methodology}

Time series econometric techniques of cointegration, Vector Autoregressive (VAR) and Impulse Response Functions (IRF) analysis are employed to examine the interactions among the variables of interest and evaluate the real motive for using Islamic banking services in Indonesia. Following a standard time series econometric technique, the investigation steps are as follows: (i) unit root and cointegration tests; (ii) VAR specification and estimation; and (iii) IRF analysis. Unit root and cointegration tests entail preliminary analyses of data series for proper specification of the VAR models. Meanwhile, IRF analysis captures the estimation results of the VAR in order to estimate relative strength of the variables of interest to shocks in other variables.

\subsection{Unit Root and Cointegration Tests}

Time series analysis requires stationary data. Stationarity is a condition of time series which has constant mean and variance distribution overtime (Gujarati, 2003). Regressing non-stationary time series may lead to spurious regression, in which a model has high $\mathrm{R}^{2}$ but there is no meaningful relationship between the variables. This produces bias and erroneous conclusion. Thus, to avoid the problems, we employ the commonly used Augmented Dickey-Fuller (ADF) and Phillips-Peron (PP) unit root tests which allows the differentiation of the variable of interest until the stationary condition is achieved. The finding of stationary series allows us to proceed to the next test.

(8) They are Jambi (with Jambi University); West Sumatera (with Andalas University); Central Java and Yogyakarta (with Diponegoro University); East Java (with Brawijaya University); Jakarta (with National Islamic University Syarif Hidayatullah); South Sulawesi (with Hasanudin University); South Kalimantan, South Sumatera, North Sumatera, and West Java (with Bogor Agricultural University). 
In order to examine the long-run relationship between variables in a VAR model, the Johansen and Juselius (1990) test is used. The approach is developed after Engle and Granger (1987) point out that a linear combination of two (or more) non-stationary series may be stationary and that, if such a stationary linear combination exists, the non-stationary time series are said to be cointegrated. The stationary linear combination is called the cointegrating vector and can be interpreted as a long-run equilibrium among the variables (Wooldridge, 2000; Gujarati, 2003). The Johansen-Juselius cointegration test is conducted on a typical VAR model as follow:

$$
X_{t}=\mu+\Pi_{1} X_{t-1}+\ldots+\Pi_{k} X_{t-k}+e_{t}
$$

where $X_{t}$ is a vector of non-stationary variables integrated of the same order, $\mu$ is a vector of intercept, $\prod_{k}$ is a matrix of coefficients and $e_{t}$ is an vector of error term.

Under the cointegration test, the number of cointegrating vectors is determined using the Trace Statistics (TS) and the Maximum Eigenvalue (ME) statistics. By comparing the TS and ME statistics values with their respective t-statistic values, conclusion can be made as to whether the variables are cointegrated or not. If the TS and ME values exceed the t-statistics, the null hypothesis of no cointegration $(r=0)$ is rejected and it can be concluded that there exists longrun relationship among variables in the vector. Additionally, since result of the cointegration test tends to be sensitive to the order of the VAR model, the proper choice of lag length for the VAR is also critical. The lag length can be determined by using various information criteria ${ }^{(9)}$. In this study, the lag length is determined based on Schwarz Criteria (SC) which is commonly used for the VAR model.

\subsection{VAR and IRF}

In the past, most macroeconomic studies are conducted using structural models. In these models, some variables are treated as endogenous and some as exogenous or predetermined variables (exogenous plus lagged endogenous). Thus, before estimating the model, assumptions must be made regarding treatment to the variables. Sims (1980) criticized that this decision is often subjective and all variables in a system should be treated as endogenous variables. He further suggested that working with a Vector Autoregressive (VAR) model is better than working with the structural model. A representative VAR model is already given in equation (1).

(9) The common criteria are Akaike Information Criterion (AIC) and Schwarz Criterion (SC). However, most of the time the information criteria produced consistent lag order selection in VAR model (Lutkepohl, 1991). For more discussion please also see Grasa, 1989. 
Traditionally, studies adopting the VAR model employ variables in log level (see, for example, Sims 1980 and 1986). The problem is that the result from such a specification may be spurious and misleading if log level variables are non-stationary. Thus, integration and cointegration tests previously discussed are necessary to avoid spurious regression and misspecification problems. In particular, the findings that the variables are non stationary and are not cointegrated suggest the use of VAR model in first difference. However, if they are cointegrated, a Vector Error Correction Model (VECM) needs to be used (Engle and Granger, 1987). Since the VECM can be re-parameterized to form an equivalent VAR model in level form, the level VAR can also be used (Masih and Masih, 1997; Ibrahim, 2006). Moreover, using the VAR in level has several advantages to deal with dynamic behavior. The most notable argument in favour of it is the low computational burden and the rich economic interpretation attached to the associated impulse-response functions. While the impulse-responses from the VECM tend to imply that the impacts of certain shocks are permanent, those from the level VAR allow history to decide whether the effects of shocks are permanent or not (Ramaswamy and Sloek, 1997; Ibrahim, 2006; Kassim et al., 2009).

An impulse response function (IRF) measures the time profile of the effect of shocks at a given point in time on the (expected) future values of variables in a dynamical system (Pesaran and Shin, 1998). The IRF is simulated from the estimated VAR. The generation of IRF is that innovations in VAR equations may be contemporaneously correlated. This means that a shock in one variable may work through the contemporaneous correlation with innovations in other variables and isolated shocks to individual variable may not be adequately represented. To solve the issue, it is common to orthogonaliz the innovations using the Cholesky decomposition (Sims, 1980). However, result from the approach is found to be sensitive to the ordering of the variables. Therefore, Pesaran and Shin (1998) developed generalized impulse response functions to circumvent the ordering problem inherent in the orthogonalized model.

\subsection{Data and Variables}

In determining the factors influencing the saving behavior among the Islamic banks' customers, in line with the earlier studies, three major objective variables are being considered: Islamic deposit, rate of return, and interest rate. In addition, as national income normally influences the level of public saving, we incorporate national income variable in our model. Also, as banking network is believed to be an important factor in mobilizing more Islamic deposit within the banking system, we include the Islamic bank network variable in the VAR model. Thus, this study estimates a five-variable VAR model using real mudarabah investment deposit, real interest rate, real rate of return, number of 
Islamic banks' branches and real income as the variables. Specifically, the study focuses on the following system:

$$
\text { LNRDEP }=f\{\text { RR1, RI, LNBRANCH, LNIPI }\}
$$

where LNRDEP is the real level of mudarabah-investment deposit in Islamic banks (in $\log$ form), RR1 is the real rate of return for 1-month mudarabah-investment deposit in Islamic banks (lag 1 month), RI is the real interest rate for 1-month time deposit in conventional banks, LNBRANCH is the number of Islamic banks' branches (in log form), and LNIPI is the industrial production index (in log form).

The real level of Islamic banks deposit, the first variable, is measured by the total of mudarabah investment deposits in the Islamic banks including the 1, 3, 6, and 12 months investment deposits in rupiah, adjusted to the Consumer Price Index $(2002=100)^{(10)}$. Second, the real rate of return for 1-month mudarabah investment deposit (lag 1 month $^{(11)}$ ) in rupiah is used as the proxy for the return to the total mudarabah investment deposit in Islamic banks, net of inflation effect ${ }^{(12)}$. The relation between the rate of return and the level of Islamic deposit is estimated to be positive. Higher rate of return in the previous month is expected to be able to keep the existing depositors and attract new depositors, which in turn increase the deposit level. Furthermore, the real interest rate for 1month time deposit is employed as the conventional interest rate proxy ${ }^{(13)}$. The relationship between the interest rate and the level of mudarabah deposit is estimated to be negative. Higher interest rate paid by the conventional banks could potentially attract the Islamic banks' investment account holders to transfer their funds to the conventional banks and decrease the deposit level in the Islamic banks.

Industrial Production Index $(2000=100)$ is employed as the proxy to income, a major macroeconomic indicator potentially affecting Islamic banking growth. The index is commonly used as proxy for economic activity or national income primarily due to the unavailability of real GDP or GNP measures on a monthly basis (Rohmah, 2006; Kassim et al., 2009). Finally, the number of

(10) The deposit is the main type of Islamic deposit which captures close to 60 per cent of the total deposits of the Islamic banks.

(11) It is important to note that, instead of using the current real return, the one-month lag of Islamic banks return is used to reflect the prohibition of predetermined return paid to its depositors upon the deposit. Thus, since rate of return on the deposit is usually declared at the end of each month, the previous month's rate of return can be used as the indicative rate for current month.

(12) The 1-month mudharaba-investment deposit is chosen as it represents more than 50 per cent of the mudharaba-investment deposit of the Islamic banks.

(13) This type of deposit is the main type of time deposit which captures around 70 per cent of the total time deposit in the Indonesian banking system. 
Islamic banks' branches is used as a proxy for bank's network (people's accessibility to Islamic banks). The number of Islamic banks' branches is defined as the sum of branch offices, sub-branch offices, shari'ah services unit $^{(14)}$, and cash offices ${ }^{(15)}$ of the Islamic banks.

Banking data are obtained from various publications of the Indonesian central bank which cover all banks in Indonesia. As of August 2007, there are 130 conventional commercial banks, three Islamic commercial banks, and 24 Islamic Banking Units (of the conventional banks) in Indonesia. Macroeconomics data, including industrial production index and inflation data, are obtained from the National Statistical Bureau of Indonesia. The study covers the period from March 2000 to August 2007.

\section{Results and Analysis}

\subsection{Unit Root Tests and Johansen Cointegration Test Results}

The unit root tests are conducted to determine the stationarity property of the series. Prior to the tests, deterministic trend and constant in the data are evaluated and included where relevant. Table 1 depicts the results of the Augmented Dickey-Fuller (ADF) and Phillips-Perron (PP) tests for each variable. The ADF test indicates non-stationarity in levels but stationarity in first differences for all variables. These results are confirmed by the PP tests' results. Therefore, it can be concluded that these variables are integrated of order 1, i.e., I (1) is observed in the series. Overall, it suggests the possibility of long-run relationship among the variables.

Table 1. Results of Unit Root Tests.

\begin{tabular}{|l|c|c|c|c|}
\hline \multirow{2}{*}{ Variable } & \multicolumn{2}{|c|}{ ADF Test } & \multicolumn{2}{c|}{ PP Test } \\
\cline { 2 - 5 } & At level & First difference & At level & First difference \\
\hline LNRDEP & -0.668 & $-8.207^{* *}$ & -0.749 & $-8.220^{* *}$ \\
\hline LNBRANCH & -0.377 & $-10.192^{* *}$ & -0.699 & $-10.005^{* *}$ \\
\hline LNIPI & -2.958 & $-3.840^{* *}$ & -0.551 & $-15.022^{* *}$ \\
\hline RI & -1.646 & $-3.283^{* *}$ & -1.123 & $-3.283^{* *}$ \\
\hline RR1 & -2.196 & $-11.783^{* *}$ & -2.163 & $-11.732^{* *}$ \\
\hline
\end{tabular}

Notes: The test statistics are compared to the critical values from MacKinnon (1996).

$* *$ and $*$ indicate significance at $1 \%$ and $5 \%$, respectively.

(14) Shari'ah Services Unit is a special unit in the head office which functions as the head office of the branch offices, sub-branch offices and or shariah unit. Shari'ah unit itself is a special unit in the branch or sub-branch offices whose activities are to mobilize funds, channel funds, and provide other banking services based on shari'ah principle in their preparation to be shari'ah branch office (Bank Indonesia Regulation PBI No.8/3/PBI/2006).

(15) Cash Office is an office below Branch Office whose business operations assist its parent Branch Office except in channeling of Funds (Bank Indonesia, 2006) 
Given the above observations, the study proceeds with the JohansenJuselius (1990) cointegration test to evaluate the existence of long-run relationship between the variables. Since the cointegration test is sensitive to the lag structure of VAR model, optimal lag length needs to be determined before conducting the test. Based on the Schwarz Criterion test, lag 1 is suggested as the optimal lag length. Results of the cointegration test are presented in Table 2. The trace statistics and the max-eigen statistics suggest the presence of two unique cointegrating vectors among the variables of interest. Thus, it can be concluded that the variables have a long-run equilibrium and hence causality relationship exists in at least one direction in the system.

Table 2. Results of the Johansen Cointegration Test.

\begin{tabular}{|l|c|c|c|c|}
\hline \multirow{2}{*}{ Null Hypothesis } & \multicolumn{2}{|c|}{ Test Statistics } & \multicolumn{2}{c|}{ Critical Values (5 \%) } \\
\cline { 2 - 5 } & Trace & Max-Eigen & Trace & Max \\
\hline $\mathrm{r}=0$ & $118.810^{* *}$ & $42.565^{*}$ & 88.804 & 38.331 \\
\hline $\mathrm{r} \leq 1$ & $76.244^{* *}$ & $38.240^{* *}$ & 63.876 & 32.118 \\
\hline $\mathrm{r} \leq 2$ & 38.005 & 17.636 & 42.915 & 25.823 \\
\hline $\mathrm{r} \leq 3$ & 20.370 & 14.271 & 25.872 & 19.387 \\
\hline $\mathrm{r} \leq 4$ & 6.098 & 6.098 & 12.518 & 12.518 \\
\hline Notes: & $\begin{array}{l}\text { The test statistics are compared to the critical values from MacKinnon-Haug-Michelis } \\
(1999) .\end{array}$ \\
& $* *$ and $*$ indicate significance at $1 \%$ and 5\%, respectively.
\end{tabular}

\subsection{Impulse Response Function Results}

The generalized IRF captures the dynamic responses of a variable of interest to innovations in the variable itself and in other variables. In the context of this study, the IRF analysis reveals the reaction of the Islamic deposit to all the variables in the system, thus allowing the determination of the significant variable affecting the Islamic deposit.

The IRF results are shown in Fig. 2 and 3. In all cases, the results are reported over a 24-month horizon in order to analyze the persistence of the shocks. These plots are given together with two standard deviation bands in order to provide some idea of uncertainty surrounding the estimated response. Generally, if the zero line is not within the bands, then the responses are significantly different from zero. Thus, responses must be inside the bands to be statistically significant. 

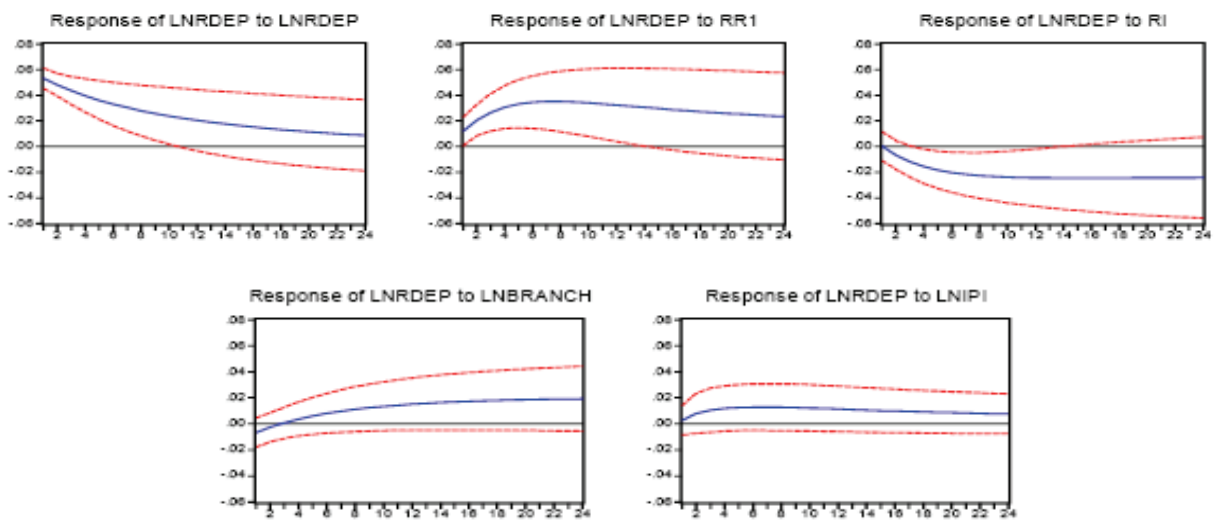

Fig. 2. Generalized Responses of Real Mudarabah Investment Deposit.

Figure 2 shows the generalized responses of Islamic deposit to shocks of the other variables. Apart from shock in itself, real rate of return and real interest rate are found to be significantly affecting the Islamic deposit level in the longrun, yet with different magnitude and time profile. Specifically, while the Islamic deposit responds positively and immediately to innovations in the real rate of return, it responds negatively to shocks in the real interest rate after some lags. The positive response of the Islamic deposit occurs immediately after the real return shocks and lasts for approximately 14 months. In other words, the customers of Islamic banks are "rational" depositors who are driven largely by the return that they get from saving. This finding concurs well with that of Haron and Ahmad (2000), Mangkuto (2004), and Rohmah (2006). However, this finding is contrary to the results obtained by the study of Bank Indonesia (2005b) in South Kalimantan, South Sumatera, North Sumatera, and West Java provinces which suggest that the rate of return is not a significant factor in determining the depositors' decision to choose Islamic banks ${ }^{(16)}$. The conflicting results could be due to the different methodology and shorter study period adopted by the study ${ }^{(17)}$. Additionally, the contrary results were not found in other provinces where the surveys were also conducted. Therefore, it can be concluded that higher rate of return encourage more savings in the Islamic bank.

(16) Only $0.3 \%$ (West Java), 0.6\% (South Kalimantan and North Sumatera), and $6.6 \%$ (South Sumatera) from total respondents that considered the rate of return is an important factor in choosing Islamic banks (Bank Indonesia, 2005).

(17) The Bank Indonesia study used qualitative methodology based on sampling method and questionnaires which are subjected to many control variables such as the amount of Islamic deposits, occupation, and location of residences. 
As expected, shocks in real interest rate of conventional banks affect the Islamic deposit negatively, after some lags. The effect lasts for about 11 months, starting approximately from the third until the $14^{\text {th }}$ month, implying that rising real interest rate leads to temporarily lower amount of the Islamic deposit. This result is confirmed by the finding of Bank Indonesia (2005-2007) which reported that in the third quarter of 2005, when the real interest rate exceeded the real return by close to 2.5 per cent, the growth of Islamic deposit was only 0.4 billion rupiah (quarter-on-quarter) due to significant withdrawal and transfer of funds, especially from 'large' depositors (i.e., corporations and individual investors with large denomination of funds), from the Islamic banks to the conventional banks. While it was also evident that the funds were 'returned' to the Islamic banks in the following quarters, where gap of the rates decreased, it came at the expense of lower growth of Islamic banks' profit due to higher re-allocation of some operational income to the profit sharing margin in effort to retain the Islamic banks' competitiveness (Bank Indonesia, 20052007). The result is also consistent with that of Kassim et al., (2009) which highlights the exposure of the Islamic banks to the displaced commercial risks in the case of Malaysia.

The study also finds that the response of Islamic deposit to shocks in the number of the Islamic bank branch appears to be positive but insignificant over the long-run. In other word, given the historical condition during the period of observation, the innovations in Islamic banks' branch do not give significant impact on the Islamic banking growth. While this finding seems to be in contrary to the results of previous studies in several countries (Nasser et al., 1999; Rohmah, 2006; and Dusuki and Abdullah, 2007), as shown in Fig. 2, it has indeed contributed to a positive trend toward higher Islamic banking growth and indicated a possible permanent effect on the growth in the long-run. Finally, the result shows that even though the Islamic deposit responds positively to innovations in real income, the response is insignificant. This result is quite intuitive considering the small size of Islamic banks as compared to the conventional banks in Indonesia. As of August 2007, the total assets and total deposits of Islamic banks were only 1.66 per cent and 1.67 per cent of the national banks' share, respectively (Bank Indonesia, 2007). Thus, it is unlikely that such condition can significantly contribute to long-run income and economic growth of the country. Yet, this finding indicates that positive economic growth is important in order to support the Islamic banking development.

Another important findings based on the generalized responses are depicted in Fig. 3. The Figs. shows that the real return of Islamic deposit responds positively and significantly to shocks in real interest rate and in real mudarabah investment deposit. Interestingly, innovations in real return also influence real 
interest rate in the opposite directions such that positive innovations in the real return are immediately followed by lower real interest rate for approximately 10 months. Together with the significant response of the real return to shocks in the real interest rate, this result confirms the co-movement between the two rates in the long-run. The difference, however, can be seen from the pattern and duration of the effect. While shocks in the real return influence the real interest rate immediately, the reverse only occurs after some time lags. Real interest rate changes also affect real return considerably longer than the opposite case. Further investigation using the Granger Causality test suggests that the real interest rate is used as a benchmark for the rate of return of the Islamic deposit in the long-run ${ }^{(18)}$. The use of interest rate as a benchmark for the rate of return and pricing for other Islamic financial products, however, remains the subject of hot debate among shari'ah scholars worldwide.
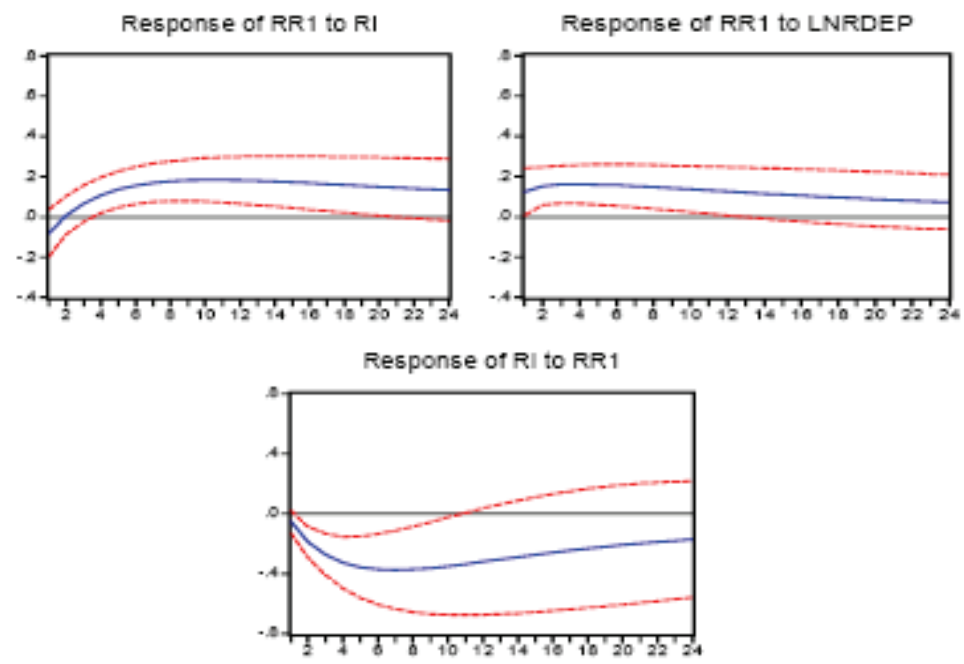

Fig. 3. Selected Generalized Responses.

Positive shocks in the mudarabah investment deposit immediately affects the real return in the same direction and diminishes after a considerable time period i.e. approximately 13 months. Since the previous finding (see again Fig. 2) shows that shocks in the real return also affect the mudarabah deposit positively, this result implies that a bi-directional long-run relationship exists between the Islamic deposit and its real return in the long-run. Theoretically, the bi-directional relationship between the Islamic deposit and real return can be

(18) While it is not the main focus of this study, we conducted the Granger causality test and further investigated the direction of short-run causality to confirm the hypothesis. It is suggested that the real interest rate granger causes the real return ( $5 \%$ significance level), therefore confirm the use of conventional interest rate as the benchmark for the real return. 
explained as follows. Higher real return increases the amount of Islamic deposits through the influence of the profit-seeking motive, while higher deposit increases the capability of Islamic banks to 'adjust' the rate of return to be as 'competitive' as the real interest rate, which in turn could encourage increase the level of mudarabah investment deposit. The additional amount of the Islamic deposit could come from the existing depositors and/or the new depositors who are attracted by the 'competitive' return. Note that if the banks are 'forced' to give part of their profit share to fulfill the consumers' expectation and stay competitive in the market, this could suggest a poor risk management practices which increase their operational expenses and reduces their profit margin. In Islamic banking context, this is known as displaced commercial risk ${ }^{(19)}$. Practically, this issue is quite difficult to be investigated due to the bank's confidentiality problem. In the long-run, these exercises could potentially limit, or even deteriorate, development of the Islamic banking industry in Indonesia.

\section{Conclusions and Recommendations}

This study attempts to determine the factors affecting saving in the Islamic banks in Indonesia. By employing the Vector Autoregressive (VAR) models, the study analyzes the importance of real rate of return on Islamic deposit, interest rate on conventional deposit, real income and number of Islamic bank branches in determining the level of savings/investment in the Islamic banks. The period of observation is March 2000 to August 2007.

By using a five-variable VAR model, the study shows that the mudarabah investment deposit - the proxy for the level of savings/investment in the Islamic banks - has positive relationship with the real rate of return on Islamic deposit and negative relationship with the real interest rate on conventional deposit. This implies that higher rate of return and lower interest rate are associated with higher level of the Islamic deposits, suggesting that the return to saving is a significant determining factor to save in the Islamic banks. In fact, return to saving is shown to be the most significant factor to save in the Islamic banks in the case of Indonesia since the two other factors under consideration, which are

(19) Islamic Financial Services Board (IFSB) introduced a more formal term, the displaced commercial risk, which can be defined as exposure when the Islamic banks are under market pressure to pay a return that exceeds the rate that has been earned on assets financed or when the return on assets is under-performing as compared with competitors' rates. In such conditions, the Islamic banks may decide to waive their rights to part or their entire mudarib share of profits in order to satisfy and retain their fund providers and dissuade them from withdrawing their funds (IFSB, 2005, Guiding Principles of Risk Management for Islamic Financial Institution. p. 23). 
number of Islamic bank branches and real income are shown to be insignificant in affecting the level of Islamic deposit in the long run. Note that, despite of these notable findings, the results of the study should be interpreted within the macro framework during the period of observation because it is indeed a generalized and aggregated study for Islamic banking industry in Indonesia.

A further investigation reveals the existence of displaced commercial risk between Islamic banks and conventional banks which is shown by the tendency of Islamic banks depositors to withdraw their fund and put it in the conventional banks when the real return provided by the bank is lower than the interest rate of its conventional counterparts (and vice versa). The existence of displaced commercial risk in Islamic banks in Indonesia should be concerned especially by the Islamic banks management and the policy maker. On the one hand, the banks' management should watch carefully the performance of their financings to gain optimal revenue. On the other hand, they must also improve their efficiencies in order to remain competitive. These would require a good risk management as well as good asset-liability management practice. This should be also concerned by the central bank.

To mitigate the displaced commercial risk, the Islamic Financial Services Board have introduced the Profit Equalization Reserves (PER) concept which is the amount set aside by the Islamic financial institutions out of their gross income in order to maintain a certain level of rate of return for their depositors. However, the PER concept has not been incorporated into Islamic banks regulations in Indonesia. In fact, most of Islamic bankers did not even realize that this instrument exists. Thus, better risk management practice should be one of the utmost concern.

The risk can be reduced by increasing the people's knowledge about the Islamic banking itself. Islamic banks' depositors that have a good understanding on the spirit of Islamic bank usually care more on the halal/haram of the transactions and the revenue from the associated business activities. Thus, they tend to be more consistent and less influenced by the movement of interest rate. This behavior reflects what should be called as a "rational Muslim depositor behavior". Accordingly, the public education activities should be done and supported by all Islamic banking stakeholders. Islamic bank should educate and motivate their costumers to save/invest in halal activities, even if this has some worldly costs. Ulama (Islamic scholars) should also educate the Muslim to change their behavior and avoid the riba transactions. Finally, an individual Muslim should also be aware that the investment choices they made should not only be based on the profit maximization but also on those returns in the hereafter. Therefore, the decision to place deposits in Islamic banks is not only to earn some profit but also to get the blessing of Allah SWT. 


\section{References}

Ahmad, N. and Haron, S. (2002) "Perceptions of Malaysian Corporate Customers Towards Islamic Banking Products and Services", International Journal of Islamic Financial Services, 3(4): 13-29.

al-Asqalani, Ibn Hajar (2003) Fathul Bary Sharh Sahih Bukhari (4th ed), Beirut: Dar al Kutub al-Ilmiyah.

Almossawi, M. (2001) "Bank Selection Criteria Employed by College Students in Bahrain: An Empirical Analysis", International Journal of Bank Marketing, 19(3): 115-125.

Bank Indonesia (2002) The Blueprint of Islamic Banking Development in Indonesia, Central Bank of Indonesia, Jakarta.

Bank Indonesia (2005) Laporan Perkembangan Perbankan Syariah 2005 [Islamic Banking Development Report 2005], Central Bank of Indonesia, Jakarta

(2006) Laporan Perkembangan Perbankan Syariah 2006 [Islamic Banking Development Report 2006], Central Bank of Indonesia, Jakarta

(2000-2007) Indonesian Banking Statistics, Central Bank of Indonesia, Jakarta.

(2007) Laporan Perkembangan Perbankan Syariah 2007 [Islamic Banking Development Report 2007], Central Bank of Indonesia, Jakarta

(2008) Kodifikasi Produk Perbankan Syariah [Islamic Banking Product Codification], Central Bank of Indonesia, Jakarta.

Bank Indonesia and Bogor Agricultural University (2005) Pemetaan Hasil Penelitian Potensi, Preferensi, dan Perilaku Masyarakat Terhadap Bank Syariah di Indonesia [Potency, Preference, and People's Behaviour Toward Islamic Bank in Indonesia: A Compilation], Central Bank of Indonesia, Jakarta.

Dusuki, A.W. and Abdullah, N.I. (2007) "Why Do Malaysian Customers Patronize Islamic Banks?", International Journal of Bank Marketing, 25(3): 142-160.

Engle, R.F. and Granger, C.W.J. (1987) Cointegration and Error Correction: Representation, Estimation and Testing, Econometrica, 55, 251-276.

Grasa, A.A. (1989) Econometric Model Selection: A New Approach. Dordrecht: Kluwer Academic Publishers.

Gujarati, D. N. (2003) Basic Econometrics, McGraw-Hill, New York.

Haron, S. and Ahmad, N. (2000) "The Effects of Conventional Interest Rates and Rate of Profit on Funds Deposited with Islamic Banking System in Malaysia", International Journal of Islamic Financial Services, 1(4): 1-7.

Haron, S. and Shanmugam, B. (1995) "The Effect of Rates of Profit on Islamic Bank's Deposit: A Note", Journal of Islamic Banking and Finance, 12(2): 18-28.

Haron, S., Ahmad, N. and Planisek, S.L. (1994) "Bank Patronage Factors of Muslim and NonMuslim Customers", International Journal of Bank Marketing, 12(1): 32-40.

Ibrahim, M.H. (2006) Stock Prices and Bank Loan Dynamics in a Developing Country: The Case of Malaysia, Journal of Applied Economics, 9(1): 71-89.

Islamic Financial Services Board (2005) Exposure Draft No.1: Guiding Principles of Risk Management for Institutions (Other Than Insurance Institutions) Offering Only Islamic Financial Services, IFSB, Kuala Lumpur.

Jalaluddin, A.K.M. (1992) Savings Behaviour in Islamic Framework, Economic Bulletin Persatuan Ekonomi, Kajian Perniagaan dan Pengurusan, Shah Alam, 2(3): 71-85. 
Johansen, S. and Juselius, K. (1990) Maximum Likelihood Estimation and Inference on Cointegration: with Applications to the Demand for Money, Oxford Bulletin of Economics and Statistics, 52, 169-210.

Kassim, S., Abd Majid, M.S. and Yusof, R.M. (2009) Impact of Monetary Policy Shocks on Conventional and Islamic Banks in a Dual Banking System: Evidence from Malaysia, Journal of Economic Cooperation and Development, 30(1).

Keynes, J.M. (1936) The General Theory of Employment, Interest, and Money, Japan: Maruzen Co., Ltd.

Lutkepohl, H. (1991) Introduction to Multiple Time Series Analysis, New York: SpringerVerlag.

MacKinnon, J.G., Haug, A.A. and Michelis, L. (1999) Numerical Distribution Functions of Likelihood Ratio Tests for Cointegration, Journal of Applied Econometrics, 14, 563-577.

Mangkuto, I.J. (2004) Pengaruh Tingkat Suku Bunga Deposito Konvensional dan Tingkat Pendapatan Deposito Mudharaba Terhadap Pertumbuhan Deposito di Bank Muamalat Indonesia, [The Effects of Conventional Deposit Interest Rate and Mudaraba Deposit Yield to the Deposit Growth at Bank Muamalat Indonesia], Unpublished Master Thesis, University of Indonesia, Jakarta.

Masih, A.M. and Masih, R. (1997) A Comparative Analysis of the Propagation of Stock Market Fluctuation in Alternative Models of Dynamic Causal Linkages, Applied Financial Economics, 7: 59-74.

Metawa, S.A. and Almossawi, M. (1998) "Banking Behaviour of Islamic Bank Customers: Perspectives and Implications", International Journal of Bank Marketing, 16(7): 299-313.

Modigliani, F. and Brumberg, R. (1954) Utility Analysis and the Consumption Function: An Interpretation of Cross-section Data. In: E.E. Kurihara (ed.), Post Keynesian Economics, New Brunswick, N.J.: Rutgers University Press.

Nasser, K., Jamal, A. and Al-Khatib, K. (1999) "Islamic Banking: A Study of Customer Satisfaction and Preferences in Jordan”, International Journal of Bank Marketing, 17(3): 135-150.

Pesaran, H.M. and Shin, Y. (1998) Generalized Impulse Response Analysis in Linear Multivariate Models, Economics Letters, 58: 17-29.

Ramaswamy, R. and Sloek, T. (1997) The Real Effects of Monetary Policy in The European Union: What are the Differences? IMF Working Paper, International Monetary Funds, $97 / 160$.

Rohmah, N. (2006) Determinants of Islamic Banks' Deposits in Indonesia: An ARDL Modelling Approach, Unpublished Master Thesis, International Islamic University Malaysia.

Sims, C.A. (1980) Macroeconomics and reality, Econometrica, 48(1): 1- 49.

(1986) Are Forecasting Models Usable for Policy Analysis? Quarterly Review, Federal Reserve Bank of Minneapolis, Winter, 2-16.

Sukmana, R. and Yusof, R.M. (2005) "Are Funds Deposited in Islamic Banks Guided by Profit Motive? An Empirical Analysis on Malaysia", Paper presented at the 4th Global Conference on Business and Economics, St. Hugh's College, Oxford University, U.K.

Usmani, M.T. (2005) An Introduction to Islamic Finance, Idara (P) Ltd, New Delhi.

Wooldridge, J.M. (2000) Introductory Econometric: A Modern Approach, South-Western College Publishing, Singapore. 


\section{المحددات التجريبية للادخار في البنوك الإسـامية: أدلة من إندونيسيا}

\section{رحمتا أوليه كاسري وسالينا حاجي قاسم}

باحث- مركز الاقتصاد الإسلامي والتجارة

كلية الاقتصاد والتجارة - جامعة إندونبسيا- إندونيسيا

وأستاذ مساعد - قسم الاقتصاد

كلية الاقتصاد والعلوم الإدارية - الجامعة الإسلامية العالمية بماليزيا

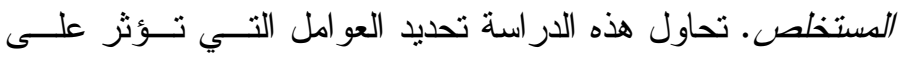

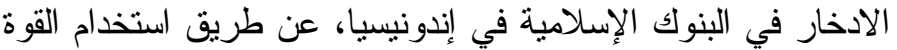

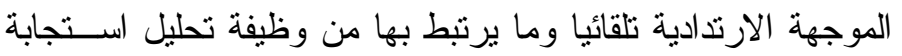

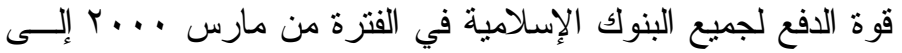

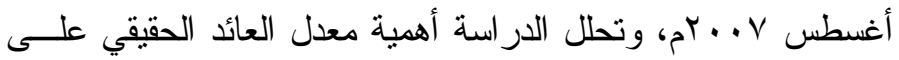

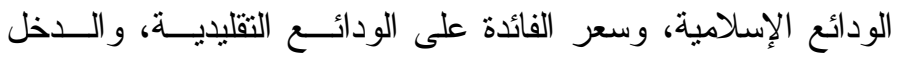

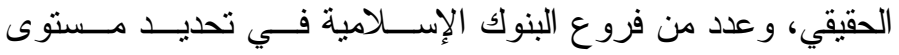

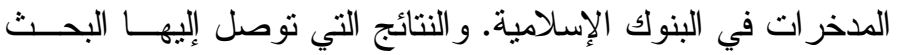

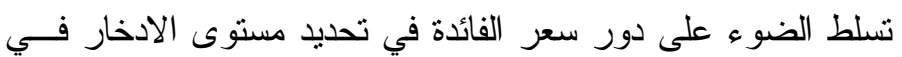

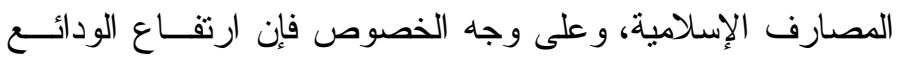

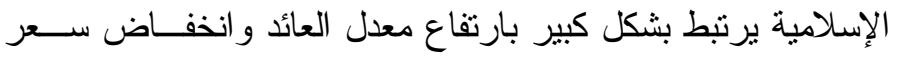

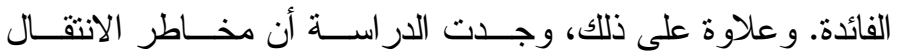

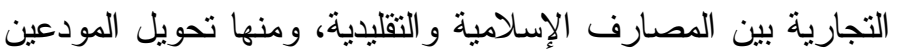

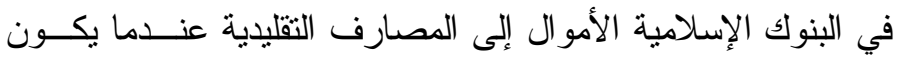

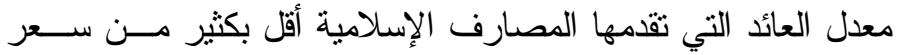

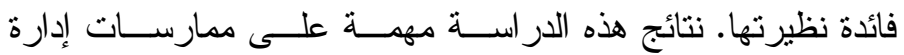
المخاطر في المصارف الإسلامية في إندونيسيا. 